\title{
GROUND BASED OBSERVATIONS SUPPORTING THE SHIPPINGPORT, PENNSYLVANIA, AERIAL RADIATION SURVEY OF FEBRUARY 1973
}

EG\&G, Inc., Las Vegas, Nevada

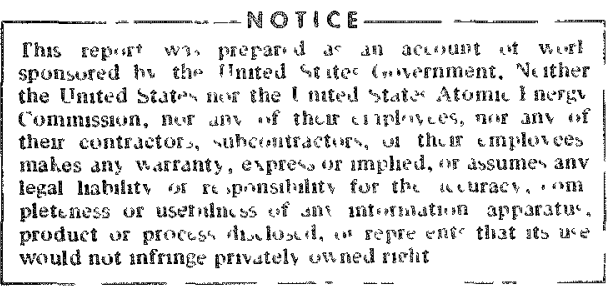

This report is part of a series on the continuing activities of the Aerial Radiological Measurung System operated for the U.S. Atomic Energy Commission. The ARMS program is managed by the Division of Operational Safety and is a cooperative effort among various offices and divisions of the Commission.

Issuance Date: May 1974

Published by

Technical Information Center, Office of Information Services UNITED STATES ATOMIC ENERGY COMMISSION 


\section{DISCLAIMER}

This report was prepared as an account of work sponsored by an agency of the United States Government. Neither the United States Government nor any agency Thereof, nor any of their employees, makes any warranty, express or implied, or assumes any legal liability or responsibility for the accuracy, completeness, or usefulness of any information, apparatus, product, or process disclosed, or represents that its use would not infringe privately owned rights. Reference herein to any specific commercial product, process, or service by trade name, trademark, manufacturer, or otherwise does not necessarily constitute or imply its endorsement, recommendation, or favoring by the United States Government or any agency thereof. The views and opinions of authors expressed herein do not necessarily state or reflect those of the United States Government or any agency thereof. 


\section{DISCLAIMER}

Portions of this document may be illegible in electronic image products. Images are produced from the best available original document. 
WORK PER FORMED BY

Coordinating Scientist

A. E. Fritzsche

Soil Moisture Measurement

D. C. Williams

Soil Sample Analysis

W. J. Tipton 


\begin{abstract}
Soil samples and tissue-equivalent dose measurements were obtained at three ground sites beneath two aerial flight lines in the Shipping port, Pennsylvania, survey area. This work was done in support of the aerial radiological survey at Shippingport on February 24, 1973. The soil samples contained naturally occurring isotopes and ${ }^{137} \mathrm{Cs}$ only. The ${ }^{137} \mathrm{Cs}$ concentration varied from 0.46 to 0.85 pico-curies per gram of dry soil. The tissueequivalent dose measurements ranged in value from 7.8 to 9.5 $\mu \mathrm{Rad} / \mathrm{hr}$, and compare well with the gamma exposure rates measured by the Aerial Radiological Measuring System (ARMS).
\end{abstract}




\section{CONTENTS}

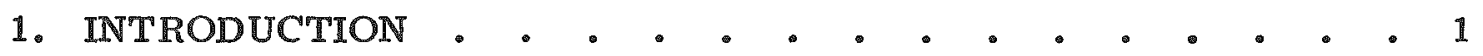

1.1 The Aerial Radiation Survey . . . . . . . . . 1

1.2 Ground Observations Program . . . . . . . . . 1

1.3 Purpose of Shippingport Ground Measurements . . . . 1

2. DESCRIPTION OF FIELD INSTR UMENTS AND METHODS . • . 2

2.1 General Remarks . . . . . . . . . . . . 2

2.2 The HPI 1010 Dosimeter . . . . . . . . . . . 2

2.3 The Soil Sampler • . • . . • . . . . . . . 2

3. DATA COLLECTION • . . . . . • . . . . . 3

3.1 Locations and Timing . . . . . . . . . . 3

3.2 Soil Samples and Site Physical Description . . . . . . 3

3.3 Soil Sample Gamma Measurements . • . . . . . 6

3.4 Dosimetry Data . . . . . . . . . . . . . . 8

3.5 Ground-Aerial Dose Comparison . . . . . . . . . 8

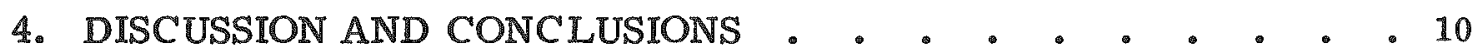

4. 1 Ground-Aerial Dose Comparison . . . . . . . . . 10

4.2 Effect of Soil Moisture . . . . . . . . . . . 10

4.3 Effect of Snow Cover . . . . . . . . . . . . 10

4. 4 Isotope Concentrations. . . . . . . . . . . . 11 


\section{INTRODUCTION}

\subsection{The Aerial Radiation Survey}

The Aerial Radiological Measuring System (ARMS) was used to survey the area surrounding the Shippingport Atomic Power Station, Shippingport, Pennsylvania, on 24 February 1973 (Ref. 1). About 530 square miles were surveyed by flying one mile spaced lines at an altitude of 500 feet. Extensive records of the gamma radiation spatial distribution and energy composition are obtained from ARMS. The results of the aerial survey are published in Reference 1.

\subsection{Ground Observations Program}

Ground based measurements in support of ARMS a re conducted on a continuing basis to: 1) verify the exposure rate conversion factor for the aerial measurements; 2 ) obtain sensitivity limits for isotope identification in the aerial measurements; and 3 ) study the environmental effects such as soil moisture, geology, snow cover, and plant cover on the aerial measurements.

\subsection{Purpose of Shippingport Ground Measurements}

Since the Shipping port survey was conducted during the winter season, the soil moisture and snow cover were expected to be quite different than during a normal survey conducted in the summer. Thus, the following data were sought, with the sampling time coinciding with the aerial survey:

(1) Dose or exposure rate at 3 feet above the ground and under flight lines.

(2) Soil moisture.

(3) Snow mass on ground surface.

(4) Radioactive isotopic content of the soil. 


\section{DESCRIPTION OF FIELD INSTRUMENTS AND METHODS}

\subsection{General Remarks}

The Shippingport ground measurements program consisted of (1) gamma dose rate measurements using a plastic ion chamber dosimeter, and (2) collection of soil samples for laboratory analysis.

\subsection{The HPI 1010 Dosimeter*}

This dosimeter employs a 2-inch diameter spherical tissue equivalent plastic ion chamber operating in the proportional region with a multiplying gain of about 4000 . The signal strength is equal to that of an 80 -liter ion chamber at atmospheric pressure. The chamber is designed to eliminate insulator leakage errors, and is covered with an aluminum can that minimizes currents due to mechanical stress.

The high gain of the multiplying ion chamber and the rugged design make the instrument useful for low level measurements in the field. Measurements were made such that the ion chamber was suspended at 3 feet above the ground with the electronics package located above it. Thus, good geometry was obtained, so the error due to the mass of the electronics package was small and not considered in the data analysis.

\subsection{The Soil Sampler}

The soil sampler was manufactured by Oakfield Apparatus Company of Oakfield, Wisconsin. It is simply a 13/16-inch I. D. steel tube with a handle. Soil samples were obtained by driving the tube into the earth to the desired depth marked on the side of the tube. The tube is withdrawn from the earth with the sample inside; then the sample is stored in a sealed plastic bag to ensure moisture retention. The separate plastic bags were stored together in a larger plastic bag for transport and storage.

*Health Physics Instruments, Santa Barbara, California. 


\section{DATA COLLECTION}

\subsection{Locations and Timing}

Figures 1 and 2 show the locations where dose measurements and soll samples were obtained. A total of three sites were involved. Sites 1 and 2 are near Beaver, Pennsylvania (Fig. 1), and Site 3 is west of Mechanicsburg, Pennsylvania and south of Hookstown, Pennsylvania (Fig.2). Sites 1 and 2 were only 500 feet apart, but in different farm fields. Location data and aerial survey data are as follows:

$\begin{array}{lccc} & \text { Site 1 } & \text { Site 2 } & \text { Site 3 } \\ \text { Latitude } & 40.710 \mathrm{~N} & 70.710 \mathrm{~N} & 40.563 \mathrm{~N} \\ \text { Longitude } & 80.358 \mathrm{~W} & 80.357 \mathrm{~W} & 80.473 \mathrm{~W} \\ \text { Survey Line No. } & 12 & 12 & 7 \\ \text { Survey Leg No. } & 10 & 10 & 21 \\ \text { Survey Spectrum No. } & 20 & 20 & 39 \\ \text { Clock Time (EST) } & 1200-1300 & 1301-1400 & 1600-1730\end{array}$

The ARMS aircraft was observed to survey within a 200-ft horizontal distance of Sites 1 and 2 and within a 500-ft distance of Site 3.

\subsection{Soil Samples and Site Physical Description}

The ter rain is rolling over the entire Shippingport survey area with virtually no flat a reas more than $1 / 4$ mile in diameter. The ground data were obtained near hilltops at each site. Site 1 was pasture land; Sites 2 and 3 were grain stubble.

At Sites 1 and 2, snow covered about $50 \%$ of the land surface in the open fields and $100 \%$ in the wooded areas. At Site 3, there was no snow in the open fields and $100 \%$ cover in the wooded areas. The snow mass was not measured, but it is estimated at less than $1 \mathrm{~g} / \mathrm{cm}^{2}$.*

*The snow was too shallow to measure with a snow tube. 


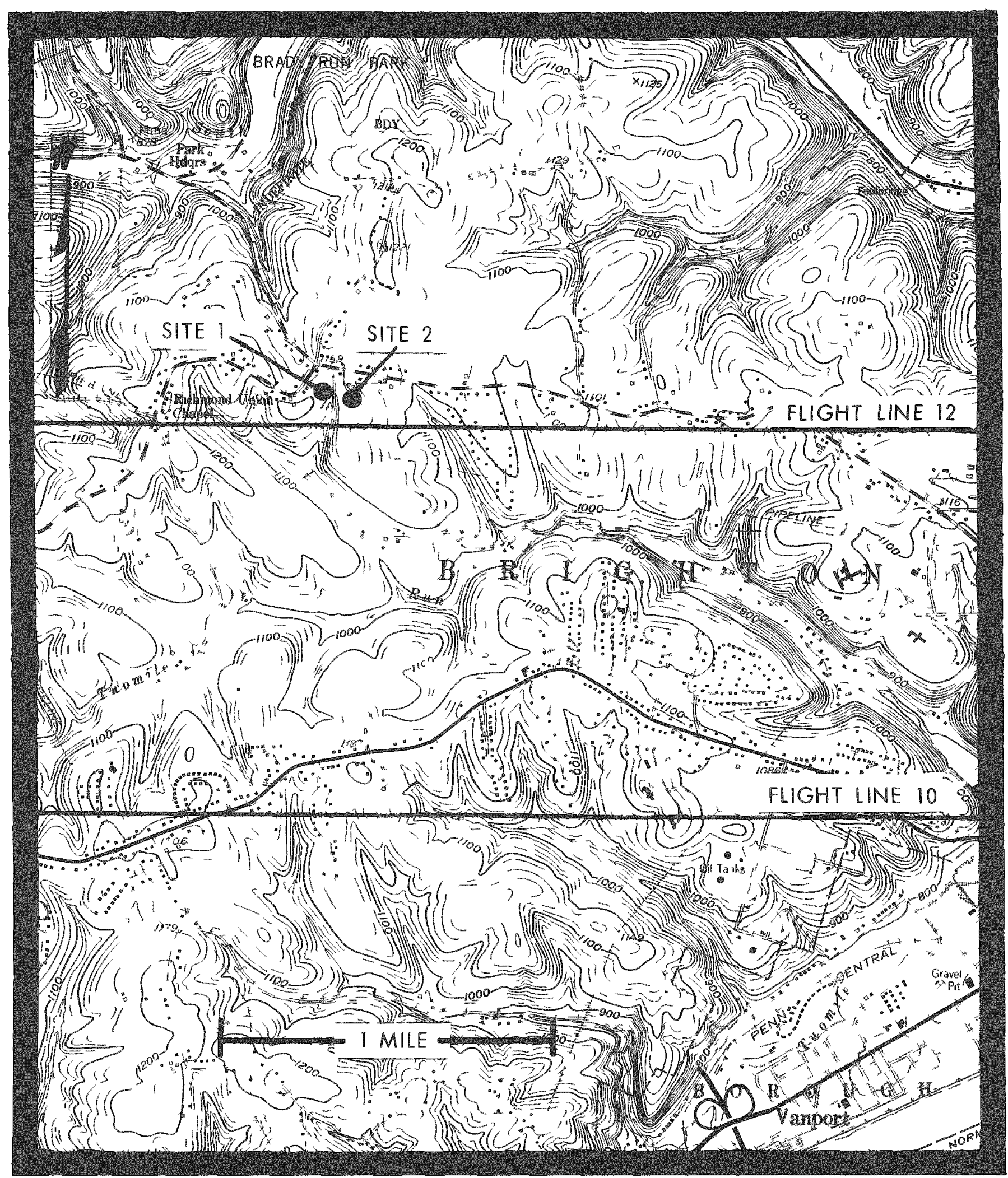

FIGURE 1. Ground measurement Sites 1 and 2 near Beaver, Pennsylvania. 


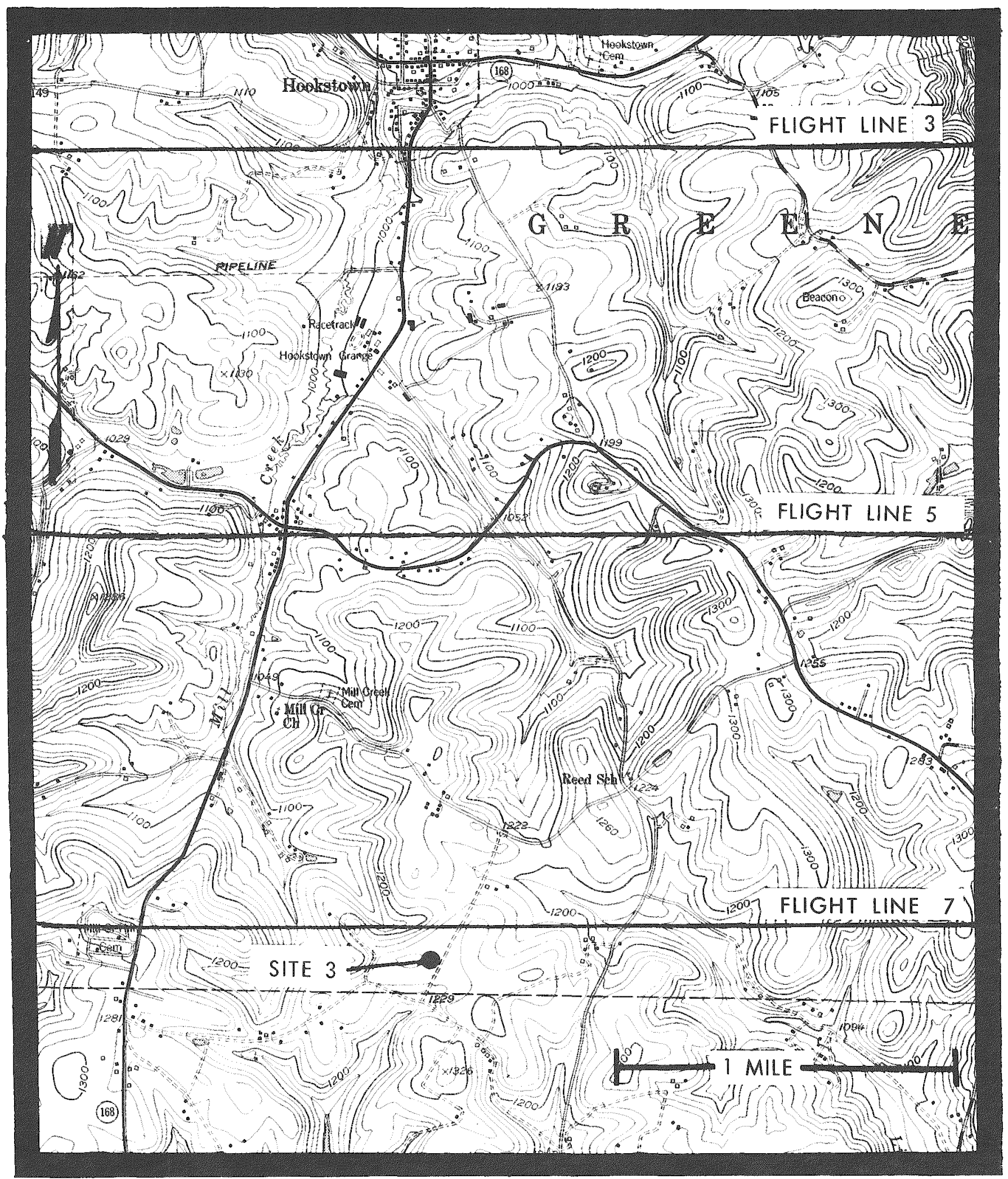

FIGURE 2. Ground measurement Site 3 near Hookstown, Pennsylvania. 
About $50 \%$ of the soil samples were frozen. Obvious frozen-frosty bands were observed in some soil samples.

Three separate 4 -inch deep soil samples were collected in one small plastic bag. Each bag weighed about $100 \mathrm{~g}$, and a total of 7-10 sample bags were obtained at each site. The samples were dried and the percent moisture for each was determined in the EG\&G Las Vegas Laboratory. The soil moisture and the standard error of the sample data for each site is listed below:

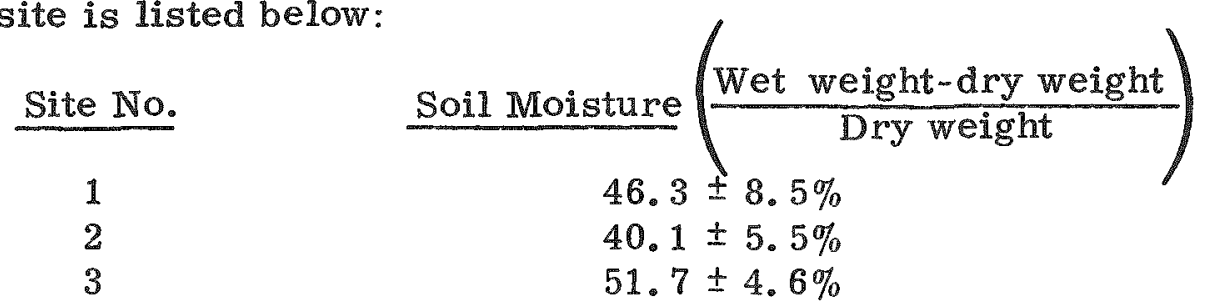

\subsection{Soil Sample Gamma Measurements}

After the samples were dried, they were packed to a density of $1.3 \mathrm{gm} / \mathrm{cm}^{3}$ inside a 5 -inch diameter by 1 -inch thick plastic petri dish. Each sample was then placed directly underneath a $77 \mathrm{~cm}^{3}$ (14.8\% relative efficiency) $\mathrm{Ge}(\mathrm{Li})$ detector located inside a low background iron shield with 8 -inch thick walls, and counted for two hours. Figure 3 illustrates the results for sample \#1 (Site 1). These results are typical of all three samples. Natural isotopes due to the uranium and thorium series, as well as ${ }^{40} \mathrm{~K}$, are readily observed. In addition, all three samples clearly indicated the presence of ${ }^{137} \mathrm{Cs}$. No other manmade isotopes could be identified. The shield background was counted for 17 hours with an empty petri dish inside to check for any possible ${ }^{137} \mathrm{Cs}$ contamination. None was found.

To obtain a rough estimate of the ${ }^{13 \%} \mathrm{Cs}$ concentration within the soil samples, a calibrated ${ }^{13 \%} \mathrm{Cs}$ point source $(0.51 \mathrm{uCi} \pm 5 \%$ ) was placed $2-1 / 2$ inches off the detector axis and buried $1 / 2$ inch deep in the soil. The assumption was made that a point souce at this position would give the same number of counts in the photopeak as a uniformly distributed source having the same activity. Using this calibration technique, the following concentrations were obtained: 


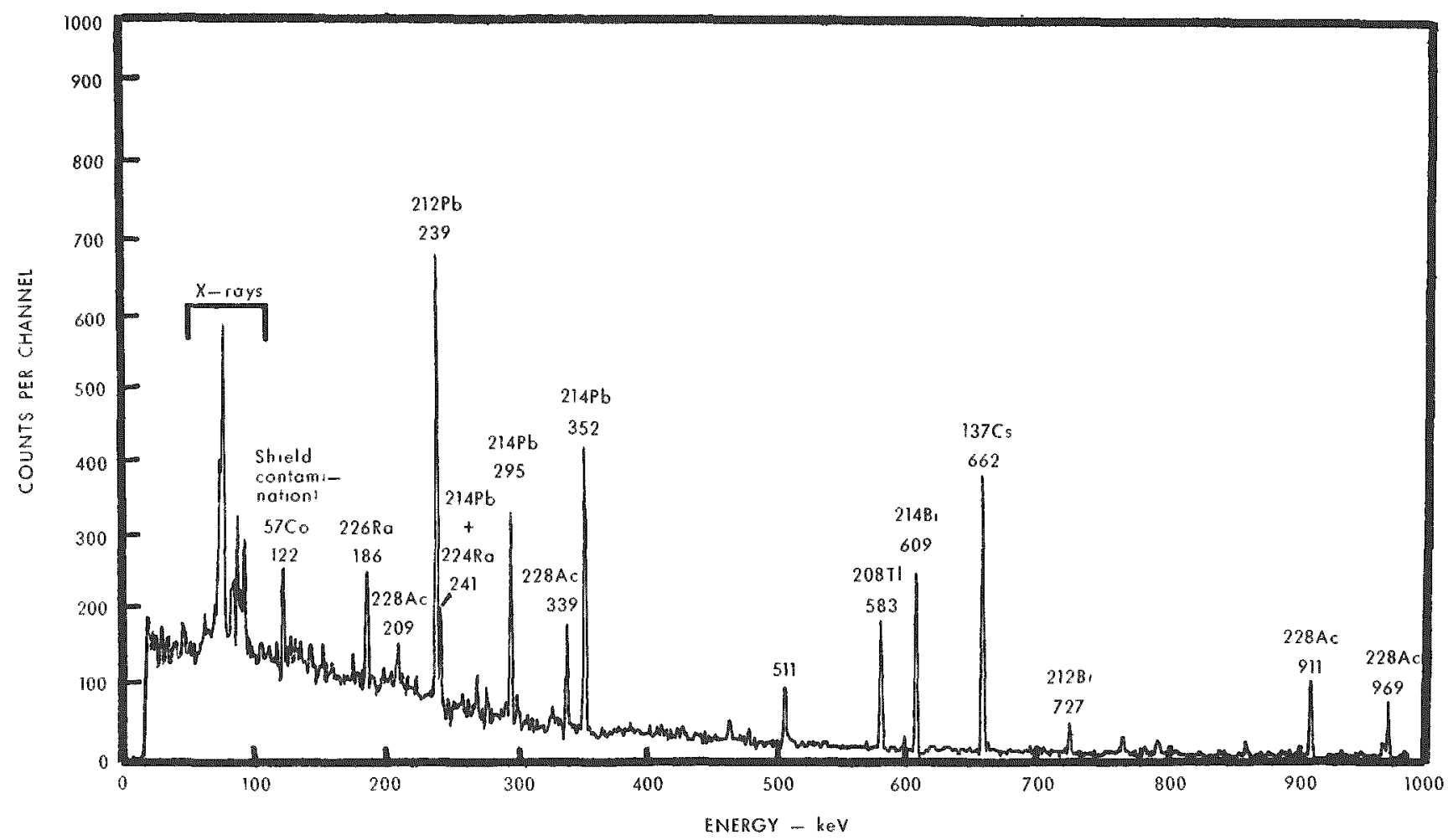

FIGURE 3A. Soil sample gamma energy spectrum, Site 1, Beaver, Pennsylvania.

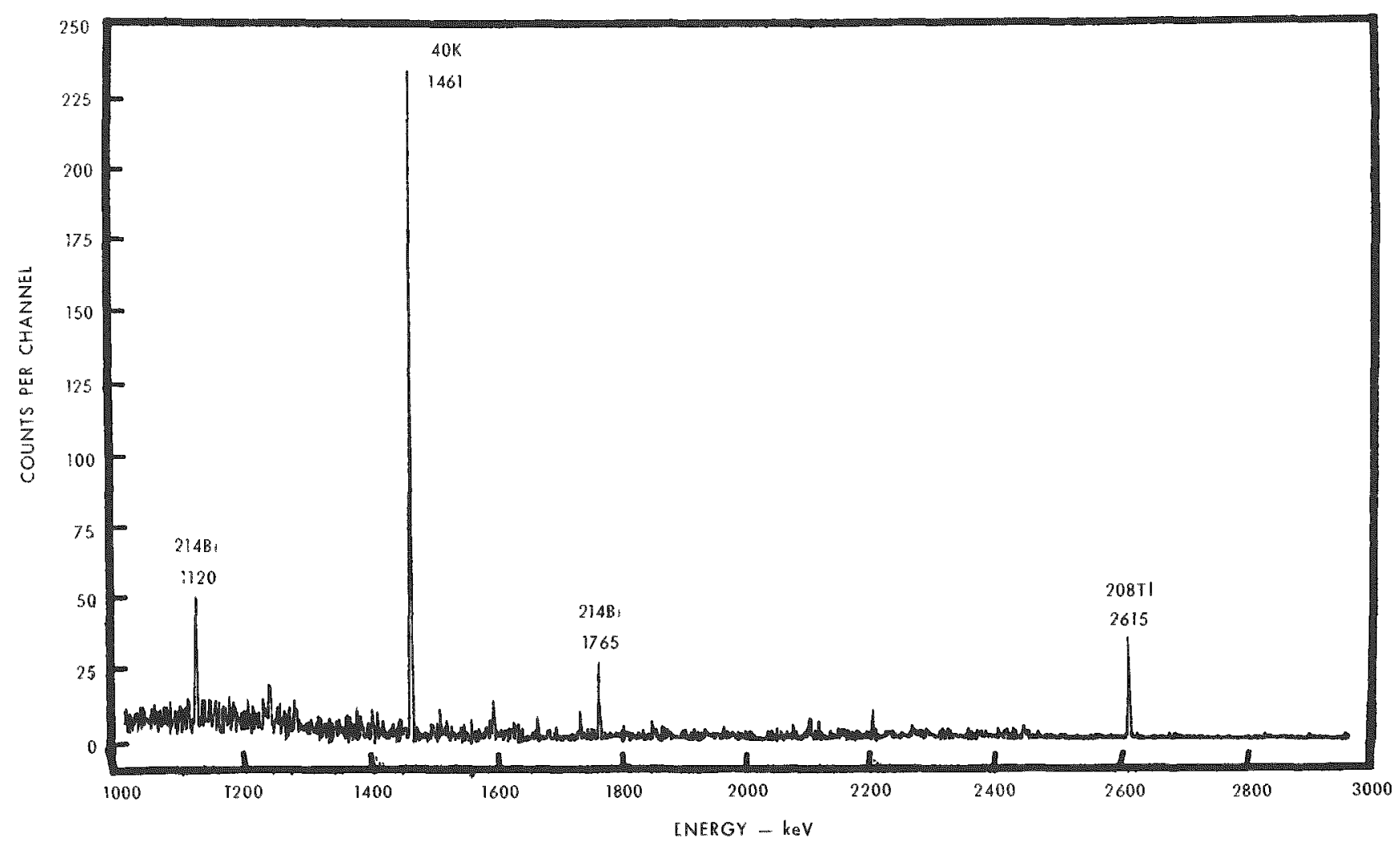

FIGIRE 3B. Soil sample gamma energy spectrum, Site 1, Beaver, Pennsylvania. 


$\begin{array}{cc}\text { Site No. } & \frac{{ }^{137} \mathrm{Cs} \text { Concentration }(\mathrm{pCi} / \mathrm{gm})}{1} \\ 2 & 0.85 \\ 3 & 0.41 \\ & 0.46\end{array}$

Although the calibration technique was not optimal, the results should be within a factor of 2 of the actual concentrations.

\subsection{Dosimetry Data}

Tissue-equivalent dose measurements at $3 \mathrm{ft}$ above the ground were made at each site -- three measurements at Site 1, one at Site 2, and four at Site 3. Each measurement required approximately 20 minutes (live radiation measurement time). The average tissueequivalent dose at each of the Sites 1,2 , and 3 was $12.3,14.0$, and 12. $4 \mu \mathrm{Rad} / \mathrm{hr}$, respectively, uncorrected for dosimeter background.

The dosimeter background was found to be $4.5 \pm 0.5 \mu \mathrm{Rad} / \mathrm{hr}$. This was obtained by multiple measurements in a low background level shield in the EG\&G Laboratory. The background in the dosimeter is due primarily to alpha particles from natural isotopes in the ion chamber walls. The error $(0.5 \mu \mathrm{Rad} / \mathrm{hr})$ in the background contributes to the standard error of the measurement.

The other principal error in the measurement is the dosimeter calibration error, which is about $5 \%$ of the value measured.

The tissue-equivalent dose at each site was as follows:

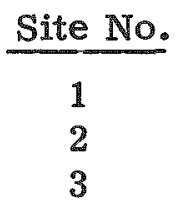

$$
\begin{aligned}
& \text { Tissue-Equivalent Dose } \\
& 7.8 \pm 0.8 \mu \mathrm{Rad} / \mathrm{hr} \\
& 9.5 \pm 0.9 \mu \mathrm{Rad} / \mathrm{hr} \\
& 7.9 \pm 0.8 \mu \mathrm{Rad} / \mathrm{hr}
\end{aligned}
$$

\subsection{Ground-Aerial Dose Comparison}

The ground measurements were made beneath the aerial survey lines at the time of the aerial survey; therefore, direct comparison between the aerial and ground measurements can be made.

Gamma exposure rate at 3 feet above ground is determined every 500 feet along the survey line in the standard ARMS data reduction process. Coordinates of each data point are also available. The ground 
level dose rate may thus be associated with the correct aerial data. One-quarter mile of aerial data on each side of the coordinates were averaged to ensure overlap between air and ground data. The comparison is listed as follows:

Three-foot Gamma Exposure Rate

Site No. Ground Data

Aerial Data

1

$8.2 \pm 0.80 \mu \mathrm{R} / \mathrm{hr}$

$9.8 \pm 1.0 \mu \mathrm{R} / \mathrm{hr}$

$8.84 \pm 0.16 \mu \mathrm{R} / \mathrm{hr}$

2

$8.2 \pm 0.8 \mu \mathrm{R} / \mathrm{hr}$

$8.84 \pm 0.16 \mu \mathrm{R} / \mathrm{hr}$

$8.20 \pm 0.27 \mu \mathrm{R} / \mathrm{hr}$

The uncertainty in the aerial exposure is the standard error of the five data points. The exposure rates (in $\mu \mathrm{Rad} / \mathrm{hr}$ ) from the ground based data were obtained by dividing the measured tissue-equivalent dose rates (in $\mu \mathrm{Rad} / \mathrm{hr}$, Section 3.4 ) by .96 as recommended by the International Commission on Radiological Units and Measurements (Ref. 2). 


\section{DISCUSSION AND CONCLUSIONS}

\subsection{Ground-Aerial Dose Comparison}

The aerial measurement falls within the expected error of the ground measurement at all three sites. This agreement lends credence to the aerial measurement.

The aircraft gamma detectors tend to "see" more ground than does a detector at 3 feet, especially if the ground is rough or rapidly rolling as around Shippingport. The aircraft detectors also interrogate a swath of ground because of aircraft movement. Ground cover, such as trees and snow, contribute to differences between aerial and ground determinations of 3-ft exposure. However, in spite of these fundamental differences between aerial and ground exposure rate measurements, good agreement between them has been established.

\subsection{Effect of Soil Moisture}

The melting snow causes an increase in soil moisture over average summertime values. The measured 40 to $50 \%$ soil moisture may be as much as $20 \%$ higher than the average summertime moisture content.

Since soil moisture decreases the gamma flux (Ref.3) emanating from soil, the exposure is reduced also. In general the flux and exposure are proportional to soil density. The summertime exposure rate may increase by a factor of $1.45 / 1.25=1.16$ over the exposure levels measured here. * This assumes that soil moisture was between $40-50 \%$ over the whole area surveyed by the aircraft.

\section{3 Effect of Snow Cover}

EG\& G studies of radiation transmission through snow cover (Ref. 3) show that the total flux is transmitted according to the equation:

*Here, it is assumed that the average moisture was $45 \%$ for this survey and would average $25 \%$ for a hypothetical summer survey. 


$$
\begin{aligned}
& \mathrm{N}=\mathrm{N}_{\mathrm{o}} \frac{- \text { Snow Mass }}{15.67} \\
& \mathrm{~N}=\text { total flux with snow cover } \\
& \mathrm{N}_{0}=\text { total flux without snow cover } \\
& \text { Snow Mass in } \mathrm{g} / \mathrm{cm}^{2}
\end{aligned}
$$

Thus, since the snow mass was less than $1 \mathrm{~g} / \mathrm{cm}^{2}$, the maximum flux attenuation would be:

$$
\text { Attenuation }=\frac{N_{0}-N}{N_{0}}=1-e^{-\frac{1}{15.67}} \cong 0.06
$$

The exposure rate (and flux) would have been reduced a maximum of $6 \%$ by the snow. A maximum increase of $6 \%$ in exposure rate could be expected if the snow we re removed.

\section{4 Isotope Concentrations}

Greater accuracy for the ${ }^{137} \mathrm{Cs}$ concentration would be desirable, but the absolute efficiency of the Ge(Li) detector has yet to be measured for soil sample configurations. Furthermore, since only surface samples were taken, the vertical distribution of the ${ }^{137} \mathrm{Cs}$ in the soil is not known. These two factors prevent a more precise estimate of ${ }^{137} \mathrm{Cs}$ concentration. However, the ${ }^{137} \mathrm{Cs}$ concentrations quoted herein are consistent with concentrations due to radioactive fallout from nuclear weapons tests, as measured in other parts of the United States by other investigators (Ref. 4 \& 5). The exposure at 3 feet due to the ${ }^{137} \mathrm{Cs}$ is calculated to be about $.25 \mu \mathrm{R} / \mathrm{hr}$ using the computation procedure in Reference 5. The error in this exposure estimate may be as much as a factor of 3 .

It is worth noting here that the ${ }^{137} \mathrm{Cs}$ was marginally observable in the raw spectral data from the aerial survey. Normal smoothing procedures removed the ${ }^{137} \mathrm{Cs}$ indications from the aerial spectra, as in the spectrum shown in Reference 1, Figure 3. Since the ${ }^{13^{\gamma}} \mathrm{Cs}$ is indeed present as shown by the soil sample measurements, the indications in the ARMS spectra are probably real. A concentration of $0.5 \mathrm{pCi} / \mathrm{g}$ (typical of the soil sample results) may therefore be regarded as near the ARMS minimum detectable concentration of ${ }^{137} \mathrm{Cs}$. 


\section{REFERENCES}

1. "Radiological Survey of the Area Surrounding the Shippingport Atomic Power Station, Shippingport, Pennsylvania, Date of Survey: 24 February 1973, "EG\&G/LVAO Report No. 1183 1573, March 1973.

2. NBS Handbook 85, Recommendations of the Inte rnational Commission on Radiological Units and Measurements.

3. Burson, Z. G., Fritzsche, A. E., "Snow Gaging by Airborne Radiological Surveys - Status Through September 1972," EG\&G/ LVAO Report No. 1183-1565, December 1972.

4. Phelps, P. L., et al, "A Portable Ge(Li) Detector for Field Measurement of Radionuclides in the Environment, "IEEE Trans, on Nuc. Sc. Vol NS-19, No. 1, pp 199-210, 1972.

5. Beck, H. I., DeCampo, J., Gogolak, C., "In Situ Ge(Li) and NaI (TI) Gamma Ray Spectrometry, "HASL-258, 1972. 